\title{
Formulating a biblical teaching on sex for Nigerian Christian couples: A study of 1 Corinthians 7:1-5
}

\begin{tabular}{|c|c|}
\hline \multicolumn{2}{|c|}{$\begin{array}{l}\text { Authors: } \\
\text { Olubiyi A. Adewale }{ }^{1,3} \text { (D) } \\
\text { Funke E. Oyekan }{ }^{2,3}\end{array}$} \\
\hline $\begin{array}{l}\text { Affiliations: } \\
{ }^{1} \text { Department } \\
\text { Studies, Facult } \\
\text { National Open } \\
\text { Nigeria, Abuja, }\end{array}$ & $\begin{array}{l}\text { Religious } \\
\text { y of Arts, } \\
\text { University of } \\
\text { Nigeria }\end{array}$ \\
\hline $\begin{array}{l}{ }^{2} \text { Religious Stud } \\
\text { Programme, C } \\
\text { Liberal Studies } \\
\text { University, Iwo }\end{array}$ & $\begin{array}{l}\text { lies } \\
\text { ollege of } \\
\text { Bowen } \\
\text {, Nigeria }\end{array}$ \\
\hline $\begin{array}{l}{ }^{3} \text { Department } \\
\text { Testament and } \\
\text { Literature, Fac } \\
\text { Theology, Univ } \\
\text { Pretoria, Preto } \\
\text { South Africa }\end{array}$ & $\begin{array}{l}\text { f New } \\
\text { Related } \\
\text { ulty of } \\
\text { ersity of } \\
\text { ria, }\end{array}$ \\
\hline $\begin{array}{l}\text { Research Proje } \\
\text { Project Leader } \\
\text { Project Numb }\end{array}$ & $\begin{array}{l}\text { ct Registration: } \\
\text { : E. van Eck (1) } \\
\text { er: } 2400030\end{array}$ \\
\hline $\begin{array}{l}\text { Description: } \\
\text { The authors ar } \\
\text { in the research } \\
\text { 'Africa Platforn } \\
\text { Scholars', direc } \\
\text { Ernest van Eck } \\
\text { of New Testam } \\
\text { Related Literat } \\
\text { Theology and } \\
\text { University of P }\end{array}$ & $\begin{array}{l}\text { e participating } \\
\text { project, } \\
\text { for NT } \\
\text { ted by Prof. Dr } \\
\text { Department } \\
\text { lent and } \\
\text { ure, Faculty of } \\
\text { Religion, } \\
\text { retoria. }\end{array}$ \\
\hline $\begin{array}{l}\text { Corresponding } \\
\text { Olubiyi Adewa } \\
\text { bbearers@yah }\end{array}$ & $\begin{array}{l}\text { author: } \\
\text { le, } \\
\text { oo.com }\end{array}$ \\
\hline $\begin{array}{l}\text { Dates: } \\
\text { Received: } 17 \mathrm{~A} \\
\text { Accepted: } 12 \mathrm{~N} \\
\text { Published: } 19 \mathrm{~J}\end{array}$ & $\begin{array}{l}\text { gu. } 2021 \\
\text { Jov. } 2021 \\
\text { lan. } 2022\end{array}$ \\
\hline $\begin{array}{l}\text { How to cite thi } \\
\text { Adewale, O.A. } \\
2022 \text {, 'Formula } \\
\text { teaching on sex } \\
\text { Christian coupl } \\
\text { of } 1 \text { Corinthian } \\
\text { HTS Teologiese } \\
\text { Theological Stu } \\
\text { a7079. https:// } \\
\text { org/10.4102/h }\end{array}$ & $\begin{array}{l}\text { is article: } \\
\text { \& Oyekan, F.E., } \\
\text { ting a biblical } \\
\text { x for Nigerian } \\
\text { les: A study } \\
\text { is } 7: 1-5 \text { ', } \\
\text { Studies/ } \\
\text { Idies 78(3), } \\
\text { doi. } \\
\text { ts.v78i3.7079 }\end{array}$ \\
\hline Read online: & $\begin{array}{l}\text { Scan this QR } \\
\text { code with your } \\
\text { smart phone or } \\
\text { mobile device } \\
\text { to read online. }\end{array}$ \\
\hline
\end{tabular}

The issue of sexual relations between spouses is a major cause of broken homes in Nigeria and Christian couples are not an exception. People believe that a large percentage of broken homes have the root of their problem traced to sex. The preponderance of broken homes (and homes under tension of crises) notwithstanding, most studies in this area have been from the socioscientific and medical cum psychological point of view and many more have focused on teenagers and young people to the exclusion of married couples that need healing in this regard. This article is aimed at bringing out biblical instruction concerning the issue of sex that could help to restore peace to many homes at the verge of breaking down. The focal passage is 1 Corinthians 7:1-5, which was Paul's instructions to the Corinthian church when they faced a similar problem. This article is an exegetical analysis of the passage and is read rhetorically (rhetorical analysis examines how a text persuades readers of its point of view) with the Nigerian situation in mind. It concludes that sex must be enjoyed within the ambits of marriage and within this ambit, the only reason for abstinence is mutual agreement for the purpose of prayer.

Contribution: The article upholds gender equality in initiating and enjoying sex and rejects looking down on women who request sex. It also calls for the eradication of female genital mutilation, a tradition based on making women not enjoy sex.

Keywords: Nigeria; Christian couples; 1 Corinthians 7:1-5; sexual relations.

\section{Introduction}

The first question to ask is this: Is there a need for a Nigeria Christian view of sex? For two reasons, the answer is yes. Firstly, Nigerian Christians are assailed by some wrong or rather unbiblical views about sexual intercourse from two major Christian groups: the Catholics and mainline churches and the Pentecostals. The Catholics and mainline churches consist of the Catholic Church and orthodox churches such as Anglicans, Methodists and Baptists amongst others, while the Pentecostals consist of neo-Pentecostal movements. The problem from the fundamental block is a carry-over of cultural views, the worst of which is silence about sexual matters. Discussing the problem of silence about sex in Africa, Khalthide (2003:1) said 'we often find that when we talk about sex in public, we are faced with comments like, "Don't talk about sex, we are Christians" or "Don't talk about sex, we are Africans"'. As a result of this cultural attitude of silence about sex, 'when people turn to the church for direction in sexual matters', they are usually met with stony silence or a counsel of repression, but 'silence is no counsel and repression is bad counsel' (Foster 1985:120). The Pentecostals on the other hand are having a double dose of the sex problem. Apart from the fact that many suffer from the silence syndrome, they are also highly affected by the demonising view of sex. On this issue, Khalthide (2003) said:

Perhaps the reason why the church finds it difficult to handle sex and sexuality-related issues is because we have considered sex as belonging to a domain outside the sovereignty of God. Though we may find it hard to admit, it is true that human beings, including the church, regard sex as belonging to the devil something that is associated with darkness, evil and wickedness. (p. 5)

Secondly, although the globe is facing the HIV and AIDS pandemic, Africa remains the worst hit continent. Sub-Sahara Africa had 25.3 million people living with HIV as at the end of 2020 (UNAIDS 2020 Report). As the major source of HIV is sex, it becomes necessary for Africa to forge a biblical view of sex with the aim of correcting Christian attitude towards sex. This article examines the Nigerian situation and then examines 1 Corinthians 7:1-5 to arrive at a proper attitude and view of sex applicable to the Christians in Nigeria. The choice of this passage is based on scholars' general

Copyright: (C) 2022. The Authors. Licensee: AOSIS. This work is licensed under the Creative Commons Attribution License. Note: Special Collection: Africa Platform for NT Scholars, sub-edited by Ernest van Eck (University of Pretoria). 
acceptance of 1 Corinthians 7:1-5 as focusing on sexual relationship among Christian couples. For example, Fee (1987:267-268) held that the passage is addressed to the married advising them to 'stay married with full conjugal rights'. To arrive at the core message of the passage, the rhetorical analysis method would be adopted as the focus is the appeal to persuade the readers to adopt a lifestyle or to change behaviour.

\section{Corinthians 7:1-5 in scholarship}

Undertaking a comprehensive review of 1 Corinthians 7:1-5 would be a herculean task because books and articles on 1 Corinthians from the early church fathers to contemporary days are prodigious (Thaden 2007:7). Albeit, I will attempt a brief analysis of various methodological approaches that have influenced the hermeneutics of the passage.

The first approach tagged the partition theory is exemplified in the works of Weiß. Weiß sees 1 Corinthians as made up of two different letters: 1 Corinthians 1:1-6:11 and 1 Corinthians 7:1 to the end. Consequently, he sees 1 Corinthians 7 as 'readily understandable as explicating a possible confusion, which arose from Paul's discussion of sexual immorality in letter $\mathrm{A}^{\prime 1}$ (Thaden 2007:16). With this, he has separated chapter 7 from its immediate context. However, his use of Jewish and Hellenistic contexts provided a model for reading Paul within its broader cultural contexts (Johnson 1999:21).

The next approach is that of scholars calling for the unity of the epistle. Significant among these is Margaret Mitchell who also used the rhetorical approach to examine the epistle. However, her emphasis on unity as the major theme is a major weakness because it 'obscures other equally important concerns' (Ciampa \& Rosner 2006:207). Most contemporary scholars use the rhetorical approach alongside Jewish and Hellenistic context for the hermeneutics of 1 Corinthians. This has created a clearer picture of the various issues of the epistle and the context appropriate for 1 Corinthians 7:1-5 to enhance a more appropriate understanding of the people.

New Testament scholars in Nigeria who have written on 1 Corinthians 7 have mostly avoided close examination of 7:1-5. Abogunrin (1991) upheld the euphemistic use of ä $\pi \tau \varepsilon \sigma \theta \alpha 1$. He also drew on the similarity between the Jewish and Yoruba worldviews. However, he did not go beyond seeing the passage as being more than admonition for sex within marriage. Igboin (2011) worked on 1 Corinthians 7:1-5, but was looking at it from the euphemistic usage and did not make any comment beyond the need for euphemistic expression for sex and sex organs. Ademiluka (2019) concentrated on 1 Corinthians 7:10-11 and did not even bother to examine the role of 7:1-5 as the context for 7:10-11. Ademiluka's (2014:4) position that $\alpha \pi \tau \varepsilon \sigma \theta \alpha \mathrm{l}$, which 'is better translated as "not to marry" in the view of verse 2,' is a big blow to his work as most scholars recognise its euphemistic use. Thus, most studies on 1 Corinthians 7:1-5 in Nigeria are not exhaustive and did not treat the passage as wisdom rules or an apostolic authoritative direction to follow on sexual relationship among Christian spouses, hence this article aims to fill the vacuum.

\section{Sex within marriage: The Nigerian context}

Sex is a major factor in broken homes in Nigeria. Corroborating this, Amadi and Amadi (2014:141) said 'it is estimated that $80 \%$ or more of the time marital crises are hinged on this powerful issue of our normal life - sex' and Paul (2019:253) admitted that sexual misunderstanding is a cause of dispute between couples.

The first factor affecting sex within marriage in Nigeria is the practice of female genital mutilation (Aina, Aransiola \& Osezua 2006:9). Medically, it is called clitoridectomy because it involves the removal of parts of the clitoris that plays a major role in stimulation of the woman for sex (O'Donovan 1992):

The $[r]$ eason most commonly given for female circumcision is that it ensures the wife's faithfulness to her husband in marriage by reducing the woman's sexual desires... if she is circumcised, she will not commit adultery. (p. 233)

The second factor is the effect of traditional beliefs and attitudes to sex, some of which are shown in traditional sayings. For example, a popular saying among the Yoruba people is that 'ojojumo ko lobirin nri oko re' literally meaning 'it is not possible for a woman to see her husband daily'. The word 'see' is an euphemism for sexual intercourse, thus the statement means that a woman cannot have sex with her husband daily (Adewale 2005:26; Igboin 2011:354). The truthfulness of this saying can be traced to the cultural practice of polygamy. A man with multiple wives has to equitably divide the nights among the women, thus making it impossible for any woman to have sexual intercourse with her husband daily. Unfortunately, even in the 21st century, when most Nigerian marriages are becoming monogamous, most women still hold that they cannot have sex with their husbands daily. Thus, they refuse overtures from their husbands to avoid breaking their cultural belief.

The third factor is the teaching that the original sin of mankind is sexual intercourse between Adam and Eve. This heresy is made popular by literary writers with the phrase 'the forbidden fruit' used as an euphemism for sexual intercourse. Although difficult to prove from biblical account, many Christians hold on to it. On this, O'Donovan (1992:284) said 'there is a widespread belief that the original sin of mankind was that Adam had sex with his wife (Gn 4:1), this is false'. This belief naturally leads to the belief that abstinence from sex would lead to high level of spirituality. This belief is indirectly fuelled by neo-Pentecostal churches. There are churches that request that the church workers should embark on fasting and prayer for periods ranging from 3 to 7 days in some instances and 40 to 70 days in some. It also happens that most of these workers are married women whose husbands are not members of the church. This issue creates 
tension in the home of some of these people because in their bid to be spiritual, they will want to observe the period of fasting and also want to abstain from sex during the period.

The fourth factor is the tendency among Nigerians, especially the women, to view sex as only a means of procreation. This belief is revealed in Yoruba statements such as 'je ka sere omo', that is, 'let us play the game that leads to children', which is another euphemism for sexual intercourse (Igboin 2011:354). The belief usually leads women to refuse to have sex with their husbands for a long time after the birth of a child. On this, O'Donovan (1992:289) said, 'it is common for many African wives to refuse to have sexual relations with their husbands for up to two years after the birth of a child', an indication that sex is seen primarily as a tool for procreation.

\section{The context for 1 Corinthians 7:1-5}

There is the need to discuss this briefly because context of a passage is germane in its interpretation. This is because 'disregarding the context of a passage creates a problem in the process of interpretation' (Abera 2010:10). Although traditional exegesis tends to see 1 Corinthians as a selfindependent passage taking the phrase $\pi \varepsilon \rho 1 \delta \varepsilon$ as a disclosure formula; contemporary interpretation based on rhetorical analysis says otherwise. I agree that the wider context for 1 Corinthians 7 is 1 Corinthians 1:1-6:11 while 1 Corinthians 6:12-7:7 forms a pericope. In this way, 1 Corinthians 6:12-20 becomes the immediate context and 1 Corinthians 7:1-7 the focal passage. Describing this pericope, Thaden (2007) opined:

In the first part of Paul's argument (6:12-20), in which he explains why $\pi$ opvcí $\alpha$ is to be avoided, he relies heavily on rhetography ${ }^{2}$ to get the Corinthians to see that $\pi$ opvcí $\alpha$ is incompatible with the Christian body .... In the second part of the argument (7:1-7), in which Paul teaches the Corinthians how to avoid this sexual sin, he relies more on rhetology. (p. 230 $)^{3}$

Thaden's conclusion is based on socio-rhetorical interpretation which uses rhetography and rhetology to drive argument. This being true, an understanding of the rhetography (1 Cor 6:12-20) is necessary to understand the rhetology (1 Cor 7:1-7). Explaining the interrelationship within the pericope, Marshall (2015) said:

[T] he argument in 6:12-7:7 progresses in three parts: (1) the danger of $\pi$ opveía for the body (6:12-10), (2) marriage as a solution for avoiding $\pi$ opveía (7:1-5), and (3) the conclusion of the general argument about $\pi$ opveí $\alpha$ and marriage (7:6-7). (p. 842)

With this division, the message of $6: 12-20$ is the danger of $\pi$ opveí $\alpha$ and it is the immediate context of 1 Corinthians 7:1-5.

From the brief analysis of the context for 1 Corinthians, the issue here revolves around belief about sex and issues about

2.Rhetography is defined as rhetoric that evokes images (Thaden 2007:230; cf Wanamaker 2003:203).

3.Rhetology is defined as rhetoric that evokes logical reasoning (Thaden 2007:230; cf. Wanamaker 2003:203). sexual immorality. This being the case, the situation is not too different from the contemporary Nigerian situation. Thus, the injunction of Apostle Paul to the Corinthians is apt and timely to the Nigerian situation too.

\section{Interpreting 1 Corinthians 7:1-5}

\section{Verse 1}

$\pi \varepsilon \rho \grave{~} \delta \dot{\varepsilon}$ has usually been taken as a disclosure formula and those who tow this line (see chapter 7) as commencing a new topic, however 'the formula does not mark a completely new topic, but rather highlights the transition to a new sub-

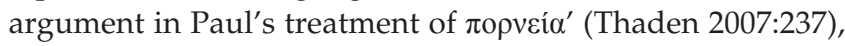

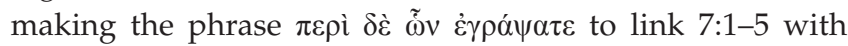
6:12-20.

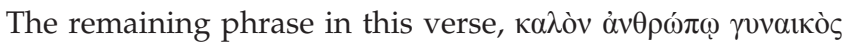

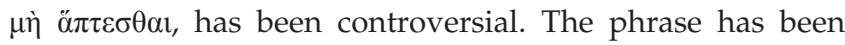
taken by some scholars as a quotation from a Corinthian letter to Paul (Collins 1999:252; Goulder 2001:125; Thiselton 2000:498-500), but as Thaden argued, it is better seen as part of Paul's rhetoric device to persuade his readers. This position is to be supported because the statement is like Paul's adoption of celibacy by those who can in 7:8. Thus, as a premise of the main argument here, Paul states his preferred position. This agrees with Garland's (2003:427-428) position that Paul 'cites the Corinthian position only to correct its dangerous misapplication .... For those already married, however, celibacy is not an option'.

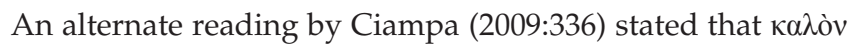

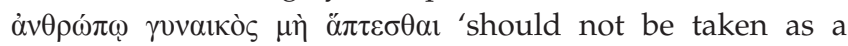
rejection of sex in general, but more likely reflects a rejection of recreational or hedonistic sex, sex for pleasure or motivated by passion'. Although Ciampa referred to ancient Greek literature from Plato, Aristotle and Plutarch alongside Jewish literature to prove that $\alpha \ddot{\pi} \tau \varepsilon \sigma \theta \alpha$ does not only mean sex but also sex used for sexual gratification. This position however

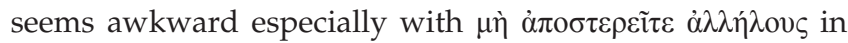
verse 5 .

\section{Verse 2}

The first thing to examine in this verse is the function of $\delta$ ì $\delta \grave{\varepsilon}$

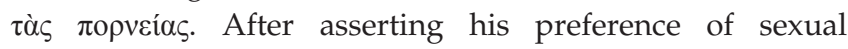
abstinence and his understanding of the fact that not everybody would be able to abstain, given the existence of sexual immorality as exemplified in chapter 5, Paul gave the alternative way of avoiding immorality: sexual relationship within marriage. Although some scholars take $\dot{\varepsilon} \chi \dot{\varepsilon} \tau \omega$ as a possessive verb and interpret the line as marriage (Fee 1987:274; Mare 1976:227), such a conclusion is out of place

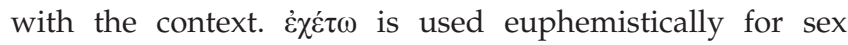
(Garland 2003:437) as ö $\pi \tau \varepsilon \sigma \theta \alpha$ in verse 1. For Abogunrin (1991:84), 'the passage is not connected with any form of marriage but with celibacy and marriage threatened by sexual asceticism'. Confirming this, Wanamaker (2005:843) said that 'Paul intends the sentence to stand as a contrary to the maxim in 1 Corinthians $7: 1 b^{\prime}$. So, the understanding of 
verse two would be that every man should have sexual intercourse with his wife and the woman is also to have sex with the husband. This interpretation accepts Paul's usage of $\gamma v v \alpha \tilde{\kappa} \alpha \alpha$ and ơ $\alpha \delta \rho \alpha$ as 'wife' and 'husband', respectively. ${ }^{4}$

\section{Verse 3}

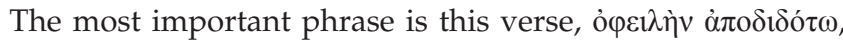
which literally means 'repay what is owed'. This again is another euphemism for sexual relationship between the husband and the wife. Hauck (1968:565) said that figuratively the word means, 'obligation' or 'duty' and that it is a euphemism for sexual intercourse that becomes a duty after a marriage and in this sense can also be translated as 'conjugal or marital duty or rights'. This is the understanding reflected in most English versions such as KJV, NIV, NASB, RSV and BBE. This understanding also buttresses the equality of both partners and this becomes full blown in verse 4 .

This verse can be considered an authoritative statement from Paul, 'the paterfamilias of the community and its members who take responsibility for their instruction and behaviour' (Wanamaker 2005:845). This means for Paul, sex within marriage is not illegal neither is it seen as a second option.

\section{Verse 4}

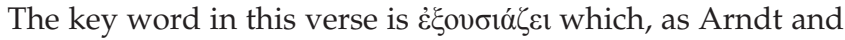
Gingrich (1957:278) indicated, means having and exercising authority in its various senses and having the right or freedom to exercise authority over or having (independent) control of something. In this sense and context, Paul seems to emphasise that in married life, the independent control of one's body according to one's inclination ceases and it becomes a joint decision of both the partners.

The verse is the peak of one new teaching of sex and sexuality that Paul did not give the man authority over the woman (neither did he give the woman authority over the man) in sexual matters. This teaching would greatly offend cultural sensibilities, wherein the man is the Lord of the jungle in sexual matters. For example, many people have it in their subconscious minds that the woman has no right to ask for sex or initiate sex and so women burn with passion rather than express it to their husbands. For Bailey (2011:202), 'equality between the wife and the husband in Christian marriage is here presented in unforgettable terms. Each partner in a marriage has authority over the body of the other'. This point is also raised by Chafin (1985:89) who said that, the sexual demands in the marriage were the same for both husband and wife. This represents a radical statement for the first century - and for today's society as well'.

A close examination of the build-up reveals that from verse 2, Paul had been balancing his statements in terms of gender.

4.There exists a debate over the best translation for yuva wo but we align with winter (2001:225-226) that it is better translated as 'wife', which would be more plausible considering the context.
In verses 2 and 3 , he mentions the husband first but in verse 4 , he brings forth the woman to the first position knowing quite well that doing that places the emphasis on the woman. This could be interpreted from two angles: firstly, it is the woman who is guilty of withdrawing her body from the man, usually as revenge tactics; secondly, it could be a means of emphasising the fact that the woman's sensibility is also of importance in sexual matters.

\section{Verse 5}

This verse is the final verse on Paul's teachings on sexual intercourse and it is the most loaded in thought. It started by

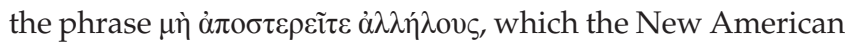
Standard Bible correctly translates as 'stop depriving one another'. Although most translations do not translate this phrase correctly, the understanding of the correct translations is of immeasurable value to the understanding of the verse and the message as in this context. The following are some of the translations:

King James Version

- 'defraud ye not one another'

New International Version - 'do not deprive each other'

Revised Standard Version - 'do not refuse one another'

Bible in Basic English - 'do not keep back from one another what is right'

Although these translations seem to have the right sense of the phrase, the interpretation of the tense and the prohibition into English is wrong. The phrase consists of the use of the negative particle ' $\mu$ 'े along with the present imperative

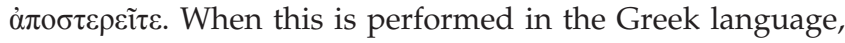
as Mounce (1993:307) indicated, 'because it is a present imperative, you know that the action being prohibited is a continuous one'. This thus implies that the sentence carries the idea of prohibiting an action already in progress (cf. Fee 1987:274).

The next important phrase is translated as 'except by agreement for a time'. The key word in this phrase is

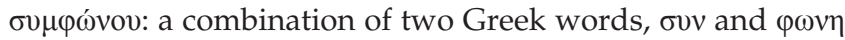
and it literally means 'sound together'. It technically talks about harmony especially in music but when it is used for human beings, it means to agree with each other (Arndt \& Gingrich 1957:788-789). This is why the New International Version used 'mutual consent'. This implies that the only exception for sex not to be part of a daily routine for married couples is basically when they both agree and the period of abstinence is also specified. The purpose for this exception is devotion to prayer.

One is now faced with the question of how long is the time expected to be? Abogunrin (1991), quoting Rabbi Ishmael, gave an idea of what may be in Paul's mind as he himself was a rabbi. He said:

[F]or married rabbis or students, abstinence must not last for more than thirty days and must be with the consent of their wives. For ordinary people abstinence from sex is only permitted for a week. (p. 84) 


\section{The message of 1 Corinthians 7:1-5}

The following are the messages that can be derived from this short passage on sex within marriage, either implicitly or explicitly:

1. Sex must be within the confines of marriage. This is implied by the statement that 'let every man have his own wife and every woman her own husband'. This maintains the Christian doctrine that sex outside is a sin.

2. Within the confines of marriage, sex becomes a duty that must be performed or a debt that has to be paid.

3. Spouses must have unlimited access to sex. No one has the right to deny the other whenever he or she wants it.

4. No one in a marriage has absolute authority over his or her body anymore and so cannot take any decision that concerns that body without reference to the other.

5. All forms of sexual deprivation that has been going on before must stop immediately.

6. Abstinence must be by mutual consent.

7. Abstinence must be for the purpose of devotion to prayer.

8. Abstinence must be allowed only for a specified period of time.

\section{Building a biblical Nigerian Christian view of sex}

Having arrived at what can be called the contextual message of 1 Corinthians 7:1-5, we can now postulate a biblical teaching of sex suitable to Nigeria.

\section{Sexual pleasure is not the exclusive preserve of men}

It has to be understood and taught that sexual pleasure is not the exclusive preserve of men and so women too should be allowed to initiate and enjoy sex. As such the practice of female genital mutilation and all other kinds of stigmatisation arising out of the attempt of women to initiate and enjoy sex has to be stopped. It has to be understood that even sexual passion is God created and every human being has the capacity and so none should be forced to suppress their feelings.

\section{Sexual intercourse can take place daily}

Apart from the periods that women are under menstruation and when there is a mutual agreement, sex can be enjoyed by both sexes. There is the need for the Nigerian women to be decolonised from the cultural perception that they cannot have sex with their husbands daily. This is far too important because most men are running away from being polygamous and so they have to fulfil their sexual desire from the one woman they are married to. Care has to be taken too because sexual dissatisfaction is one of the major causes of extramarital affairs because it is the closet alternative to the more appealing polygamy.

\section{Sex is not just for procreation}

Although not directly mentioned in the passage, Paul's decision not to link sex with marriage is an indication that he is saying that sex is not solely meant for procreation. Thus, most Nigerian women must free their mind from the idea that sex is mainly for procreation. Sex is meant to be enjoyed by both parties and not just to bring children into the world. The emphasis on children is important but it is not the only thing in marriage. Rushing to get pregnant immediately after marriage is one of the things that destroy the intimacy a couple has to build together.

\section{Sex is not sin}

A lot of Bible study has to be carried out for the purpose of teaching people that there is no iota of biblical truth in the teaching that sex is sin. Sex is a God-given gift that has to be used in line with God's own prescription and it is only when sex is taken outside God's instruction that it becomes a sin.

\section{Sex is not a tool for vengeance}

Most times both genders use sex as a tool for vengeance so that their spouse can be taught a lesson. There are times when people abstain from sex just because they want to deal with their spouse. For example, a woman refuses to have sex with her husband because the husband did not provide her the money she had asked for or a man refrains from having sex with the wife just because she nagged him.

\section{Abstaining from sex for spiritual reasons is 'pseudo-spirituality'}

Trying to avoid sex because one wants to be holy or draw closer to God is pseudo-spirituality. It has to be observed that there are people who want to avoid their conjugal responsibility under the guise of serving God. Such people should be taught that taking care of one's conjugal responsibility is in itself a spiritual service and that neglecting it does not make one's service acceptable to God.

\section{Mutual agreement in abstaining from sex}

No one has the right in a marriage to embark on abstinence from sex without the agreement of the other. The belief and practice that if you want to fast, you should not let your right hand know what your left hand is doing is not acceptable in a married life. Periods of sexual abstinence for the sake of prayer must be arrived at by the agreement and consent of both partners. If the other partner has any reason for disallowing the fasting and prayer, it has to be called off.

\section{Conclusion}

When homes are under stress and on the verge of breaking, the two main reasons for it in Nigeria are: money and sex. Unfortunately, because of the conspiracy of silence over sex in most African cultures, no one talks about it, even when they see their pastors or spiritual leaders for counselling. So, most times, the counsellors tackle the stem of the problem and leave the root to bear more stems and the problem goes on unresolved for a long time. Corinthian marriages were assailed with the issue of sex because of erroneous teachings. In the same way, Nigerian marriages are assailed with sexual issues because of wrong teachings and traditional beliefs. 
Paul resolved the Corinthian situation with his teachings in 1 Corinthians 7:1-5, so the Nigerian church too has to use the same teachings to correct the Nigerian situation.

If we are able to give the people a right biblical and divine concept of sex for our cultural situation and context, we will help people to make the best out of their marriage and at the same time help people to live a fulfilled sexual life and be contented with their wives and thereby reduce the problems of polygamy and extramarital affairs and by extension, reduce the HIV infection rate. A good sexual habit is the key to HIV reduction. The only institution that can successfully lead this crusade is the church and many are looking up to the church in this regard. The church must accept the teachings of Paul in this regard and teach it in the churches to effect changes in the sexual relationships between spouses in the church.

\section{Acknowledgements Competing interests}

The authors declare that they have no financial or personal relationships that may have inappropriately influenced them in writing this article.

\section{Authors' contributions}

O.A.A. initiated the idea of the article and worked on the following sections: The Context for 1 Corinthians 7:1-5; Interpreting 1 Corinthians 7:1-5 and the final collation of the references used by the two authors. F.E.O. wrote the introduction and the following sections: 1 Corinthians 7:1-5 in Scholarship; Sex within Marriage: The Nigerian Context, and the Conclusion. Both authors read the final draft and made necessary inputs to the final copy and approved it for submission.

\section{Ethical considerations}

This article followed all ethical standards for research without direct contact with human or animal subjects.

\section{Funding information}

This research received no specific grant from any funding agency in the public, commercial, or not-for-profit sectors.

\section{Data availability}

Data sharing is not applicable to this article as no new data were created or analysed in this study.

\section{Disclaimer}

The views and opinions expressed in this article are those of the authors and do not necessarily reflect the official policy or position of any affiliated agency of the authors.

\section{References}

Abera, A.A., 2010, 'Practical implications of 1 Corinthians 7:1-16 for Christian married couples in the Ethiopian Full Gospel Believer's Church', MA thesis, South African Theological Seminary.

Abogunrin, S.O., 1991, The first letter of Paul to the Corinthians, Daystar Press, Ibadan.

Ademiluka, S.O., 2019, 'Reading 1 Corinthians 7:10-11 in the context of intimate partner violence in Nigeria', Verbum et Ecclesia 40(1), a1926. https://doi. org/10.4102/ve.v40i1.1926

Ademiluka, S.O., 2021, 'Reinterpreting Paul's perspective of celibacy in 1 Corinthians in light of singlehood among Nigerian Christians', Verbum et Ecclesia 42(1), a2147. https://doi.org/10.4102/ve.v42i1.2147

Adewale, O.A., 2005, 'Building a biblical African Christian view of sex: An understanding of 1 Corinthians 7:1-5,' African Journal of Biblical Studies 22(1), 23-41.

Aina, O.I., Araansiola, J.A. \& Osezua, C., 2006, Sexual health and sexual rights within marriage, Understanding Human Sexuality Series, African Regional Sexuality Resource Centre., s.l.

Amadi, U.P.N. \& Amadi, F.N.C. 2014, 'Marital crisis in the Nigerian society: Causes, consequences and management strategies', Mediterranean Journal of Socia Sciences 5(26), 133-143. https://doi.org/10.5901/mjss.2014.v5n26p133

Arndt, W.F. \& Gingrich, F.W., 1957, A Greek-English lexicon of the New Testament, University of Chicago Press, Chicago, IL.

Bailey, K.E., 2011, Paul through Mediterranean eyes: Cultural studies in 1 Corinthians, IVP Academic, Downers Grove, IL.

Chafin, K.L., 1985, Mastering the New Testament: 1, 2 Corinthians, Word Publishing Company, Dallas, TX.

Ciampa, R.E., 2009, 'Revisiting the euphemism in 1 Corinthians 7:1', Journal for the Study of the New Testament 31(3), 325-338. https://doi.org/10.1177/0142064X08101527

Ciampa, R.E. \& Rosner, B.S., 2006, 'The structure and argument of 1 Corinthians: A biblical/Jewish approach', New Testament Studies 52(2), 205-218. https://doi. org/10.1017/S0028688506000129

Collins, R.F., 1999, First Corinthians, Liturgical Press, Collegeville, PA.

Fee, G.D., 1987, The first epistle to the Corinthians, Wm. B. Eerdmans, Grand Rapids, IL.

Foster, R.J., 1985, Money, sex and power, Hodder \& Stoughton, London.

Garland, D.E., 2003, 1 Corinthians, Baker Academic, Grand Rapids, MI.

Goulder, M.D., 2001, Paul and the competing mission in Corinth, Hendrickson, Peabody, MA.

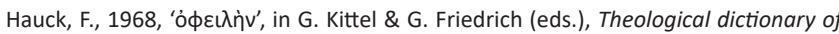
the New Testament, vol. 5, p. 565, Wm. B. Eerdmans, Grand Rapids, MI.

Igboin, B.O., 2011, 'Afro-Christian expression of sex and sex organs: A critical moral challenge to contemporary African Christianity', Evangelical Review of Theology 35(4), 345-359.

Johnson, L.T., 1999, The writings of the New Testament: An interpretation, Fortress Press, Minneapolis, MN.

Khalthide, A.G., 2003, 'Teaching and talking about our sexuality', in M.W. Dube (ed.) HIV/AIDS and the curriculum: Methods of integrating HIV/AIDS in theological programmes, WCC Publications, Geneva.

Mare, W.H., 1976, '1 Corinthians', in F.E. Gaebelein (ed.), The Expositor's Bible Commentary, vol. 10, pp. 176-303, Zondervan, Grand Rapids, MI.

Marshall, J.E., 2015, 'Community is a body: Sex, marriage, and metaphor in 1 Corinthians 6:12-7:7 and Ephesians 5:21-33', Journal of Biblical Literature 134(4), 833-847. https://doi.org/10.1353/jbl.2015.0042

Mounce, W.D., 1993, Basics of biblical Greek, Zondervan, Grand Rapids, MI.

O'Donovan, W., 1992, Biblical Christianity in African perspective, Paternoster Press, Carlisle.

Paul, K.O., 2019, 'A critical examination of broken homes in Nigeria', AGATHOS 10(1), 247-259.

Thaden, R.H., 2007, 'The wisdom of fleeing porneia: Conceptual blending in 1 Corinthians 6:12-7:7', PhD thesis, Faculty of the Graduate School, Emory University.

Thiselton, A.C., 2000, The first epistle to the Corinthians: A commentary on the Greek text, Eerdmans, Grand Rapids, MI.

UNAIDS, 2020, UNAIDS Data 2020, viewed 15 October 2021, from https://www. aidsdatahub.org/sites/default/files/resource/unaids-2020-aids-data-book.pdf.

Wanamaker, C.A., 2005, 'Connubial sex and the avoidance of porneia: Paul's rhetorical argument in 1 Corinthians 7:1-5', Scriptura 90, 839-849. https://doi. org/10.7833/90-0-1071

Winter, B.W., 2001, After Paul left Corinth: The influence of secular ethics and social change, Eerdmans, Grand Rapids, MI. 